\title{
A PROJECT MANAGEMENT UTILITY FOR AGRICULTURAL FACILITIES AND PUBLIC HEALTH
}

\author{
TILEMACHOS KOLIOPOULOS ${ }^{1 *}$, KRYSTYNA CIARKOWSKA ${ }^{2}$, JACEK \\ ANTONKIEWICZ ${ }^{3}$, SOKRATIS THEOCHARATOS ${ }^{4}$, CRINA RADU $^{5}$, ION \\ CRISTEA $^{6}$, PANAGIOTIS KOULOUMPIS ${ }^{7}$
}

\author{
${ }^{I}$ Telegeco Research Centre - University of West Attica, Department of Public Health \& \\ Community Health, Athens, Greece
}

${ }^{2,3}$ University of Agriculture in Krakow, Department of Soil Science and Soil Protection, Department of Agricultural and Environmental Chemistry, Poland;

${ }^{4,7}$ Telegeco Research Centre, Athens, Greece

${ }^{5,6}$ Vasile Alecsandri" University of Bacau, Calea Marasesti 156, Bacau, 600115, Romania

\begin{abstract}
This research study analyses the project management of agricultural facilities that protect agricultural food and public health from associated toxic hazardous landfill emissions and risks. Project management is presented by the development of a geoinformatics utility so as to improve operational management not only in food production minimizing the consumption of resources but also to improve the bio capacity development of the services and products through effective constructions minimizing risks for public health. Useful results are presented based on geoinformatics utility that develops sanitary drawings in sustainable designs minimizing risks and indoor pollution hazardous emissions in working spaces minimizing health risks.
\end{abstract}

Keywords: project management; machines; sanitary drawings; public health

\section{INTRODUCTION}

Nowadays, the environmental monitoring, surveying and investigation management software tools to minimise associated risks and environmental impacts in public health are becoming necessary for the quick and accurate monitoring of pollutants and associated hazards. Environmental hazards could be minimised by the proper project management of construction designs and right manufactures selection for decision making actions in emergencies. In this way are protected agricultural resources, food, bioremediation, reclamation works and public health $[1,2,3]$. Different but also for the spatial investigation-mapping out of lined infrastructure works in terms of ISO standards quality certification, confrontation of geographic needs, environmental impacts' mitigation, and rescue management works of an area in several emergency cases and other associated environmental risk management problems $[1,4,5,6,7,8,9,10]$. Moreover efficient geoinformatic tools are necessary for setting up proper monitoring grids for health and safety reasons in technical construction designs, project management of works, taking into account construction design openings, software tools in sanitary drawings and spatial hydrological, meteorological constraints. Therefore, several efficient informatics computer applications combined with geographic information systems (G.I.S) applications, risk assessment and associated

\footnotetext{
* Corresponding author, email: telegeco@gmail.com

(C) 2018 Alma Mater Publishing House
} 
environmental technologies are necessary so as to provide proper solutions to particular environmental management problems as they are increasing in time due to population growth needs, protecting particular socioeconomic geographic resources in agriculture, food and public health $[1,3,9,10,11,12,13,14,15]$.

A confrontation to the latter risks and hazards could be given by the right monitoring and quality assurance of manufactures and land uses through the application of quick and accurate useful geoinformatic tools in greenhouse constructions supporting them with sanitary drawing utility applications for the investigation; maintenance; support of eco-designs and monitoring of lined works on associated agricultural infrastructures. These tools are necessary for environmental management systems on several project management cases, like confrontation measures to air pollutant emissions and flood events in emergencies. In this way is protecting the public health of working staff and the biocapacity protection of agricultural infrastructures $[1,2,16]$. The ISO 14001 standard is becoming a necessary tool for investigation of environmental systems' management as well as for quality assurance of eco-design systems in manufactures for environmental protection $[8,17]$.

The proper combination of geoinformatics, numerical models and environmental software applications could provide useful software tools so as to produce any kind of technical environmental project management solutions and associated engineering drawings [4, 10, 12, 13, 14, 15, 18, 19]. Computer programming languages, web gis tools, computer aided design software tools and associated spatial analysis calculations should be used to solve quickly and efficiently several environmental monitoring and construction design problems for public health protection $[7,9,20,22,23]$. In such way new investigation methods could be developed, providing scientific progress, for lining manufactures and technical works.

\section{GEOINFORMATIC TOOLS FOR PUBLIC HEALTH PROTECTION AND PROJECT MANAGEMENT}

Several environmental problems like proper management of manufactures for ventilation or heating in greenhouses due to air pollutant emissions in greenhouse facilities as well as selection of the right pumping equipment on open canal designs so as to minimise flood events and associated risks from aquatic polluted emissions, protection of local agricultural economic geographical resources; protecting of urban-agriculturalveterinary populations and goods on flooded areas and land planning for settlement of goods on safe sites next to landfill boundaries.

Landfill gas emissions could be treated properly so as to produce energy for electricity or heating covering energy consumption necessities in greenhouse facilities. Landfill leachates should be treated so as to minimise any associated environmental impacts from toxic hazardous chemical emissions.

In this paper are investigated the carbon dioxide emissions from a small landfill facility which is located for simulation risk assessment purposes next to a greenhouse facility that operates phytobioremediation plants for the removal of heavy metals in polluted soil substrates.

At the end of the life cycle the phytoremediation plants could be used as biofuels assisting the local economy in energy consumption. The presented simulation could have application in countries under economic crisis, less developed countries and in developing countries creating new jobs and social productivity.

It is assumed that carbon dioxide emission is produced from landfill gas emissions. The presented simulation investigates the capacity of ventilation machines that is demanded for working staff's public health protection in a greenhouse facility.

Also construction design principles that should be taken into account in steel structures are discussed based on the literature for future robust designs for agricultural facilities that are in risks from fires, winds, flood events and other dynamic loadings $[6,11,24,25,26]$.

Therefore, below (Figure 1) is presented the operational project management which can be utilized for risk management and environmental impacts' minimisation combining robust numerical risk assessment spatial models and digital sanitary drawing utilities. 
The examining geoinformatic tool provides a friendly front end to the end user in VBA macros environment for Excel. The volume of a given greenhouse agricultural construction facility is necessary for the proper calculations in machines capacity for ventilation. Then the initial results are provided to front end forms in VBA macros environment for ACAD providing digital sanitary drawings. Based on the hydrological data for a given area a rectangular open canal is produced as digital drawing. The open canal should located next to a greenhouse facility protecting it from flood and polluted aquatic emissions.

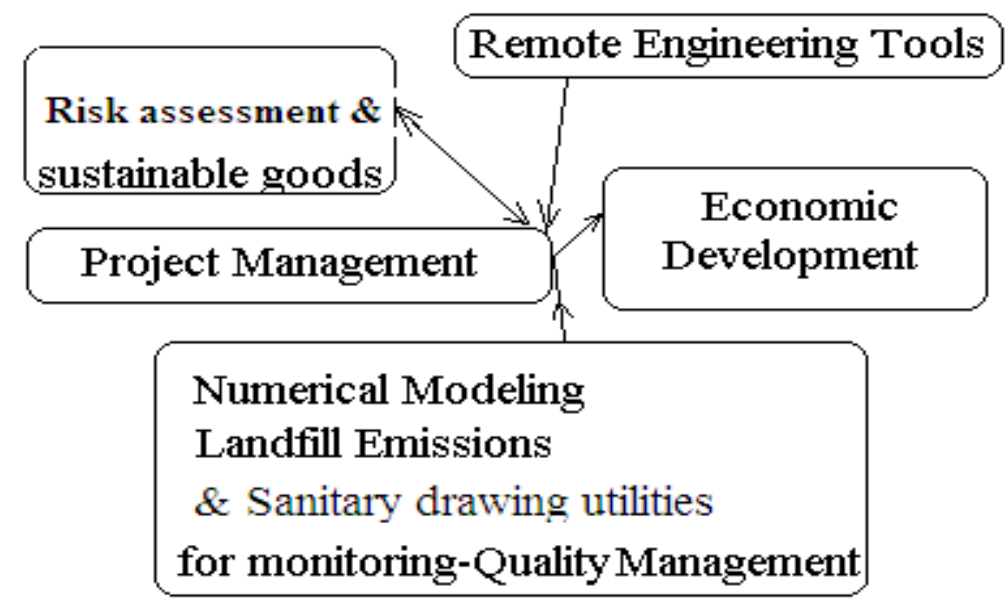

Fig. 1. The project management framework to minimize the risks and protect $\mathrm{t}$ public health in agricultural facilities.

Machines for pumping could be decided for extreme storm events based on given data for characteristic topographies and protection of soil inclinations. Also a flow chart drawing for the ventilation and air recirculation in a greenhouse is created. Some indicative figures are presented in the next section for the calculated results of the next examining formula.

Symmetrical steel portal frames could be used in greenhouse constructions for food protection and associated agricultural infrastructures providing the optimum microclimatic soil conditions for agricultural cultivations [27].

Eurocode 3 could be applied properly for steel portal frames in agricultural facilities. For any other dimensions Eurocode 3 should be applied properly in steel structures as well as for fire protection, part 1-2: General Rules Structural fire design [6].

For other construction materials should be followed other Eurocodes. Steel structures provide the benefit that could be set up in shorter time period than other construction materials, which means saving of money not only during construction management but also during the mainance operational management. In steel design of portals additional supports should be applied so as to avoid lateral buckling for big spans [24, 25, 26].

Geoinformatic utilities, e-infrastructures, risk assessment and environmental impact assessment of landfill emissions should take place so that protect the environmnetal, anthropogenic and public health resources next to a landfill site [3, 10, 15]. Sustainable designs and reclamation works are needed so as to protect agricultural, food and public health resources.

Greenhouse facilities could be used also to cultivate particular phytobioremediation plants [28,29] that could be placed properly and be used to mitigate heavy metals' concentration on polluted soil surfaces due to landfill leachate emissions on given slopes next to a landfill site area (see Figure 2).

Sustainable designs should be taken into account for the protection of phytobioremediations in floods, drainage maintenance, proper hydrological irrigation design and robust confrontation against other associated dynamic loads i.e earthquakes, top soil protection from debris flow etc. 

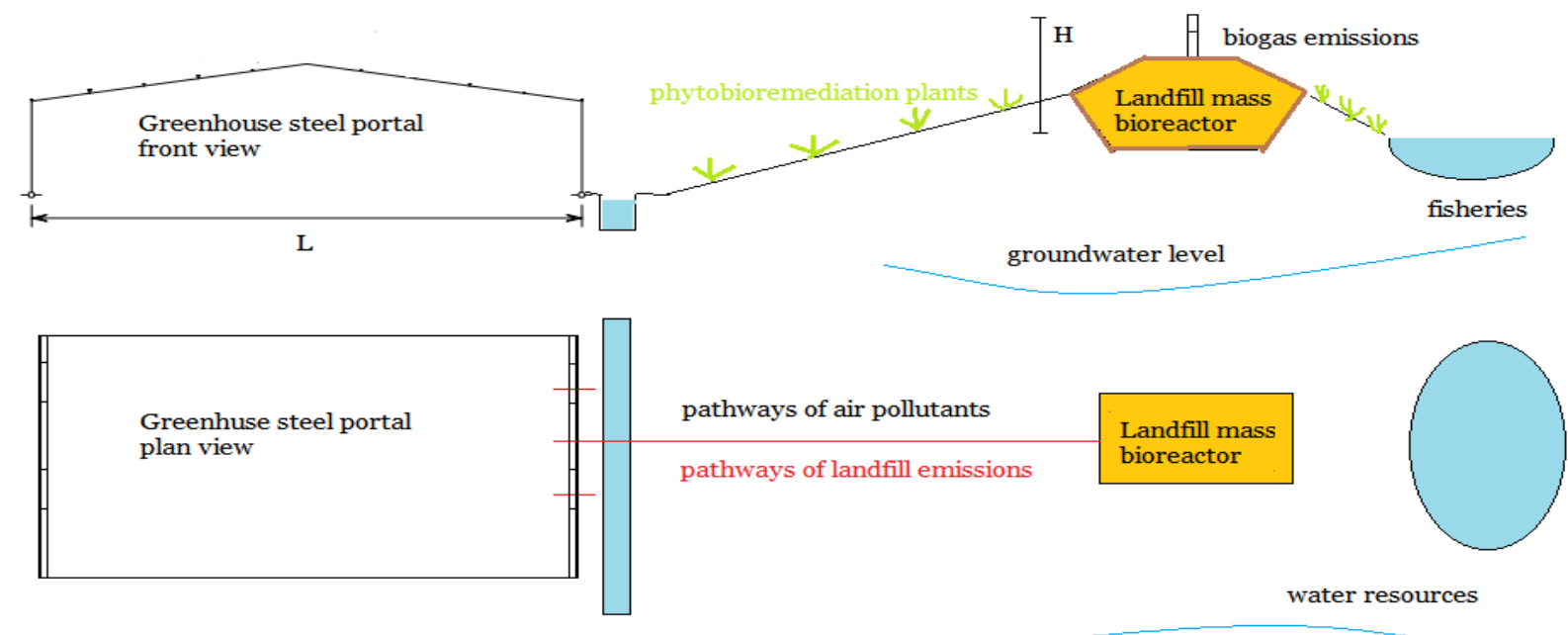

Fig. 2. Risks of sources, pathways and receptors that exist next to a greenhouse facility for a given nominal volume based on dimensions of a symmetrical single-span portal frame.

Indicative front ends of the presented geoinformatic utility are presented below.

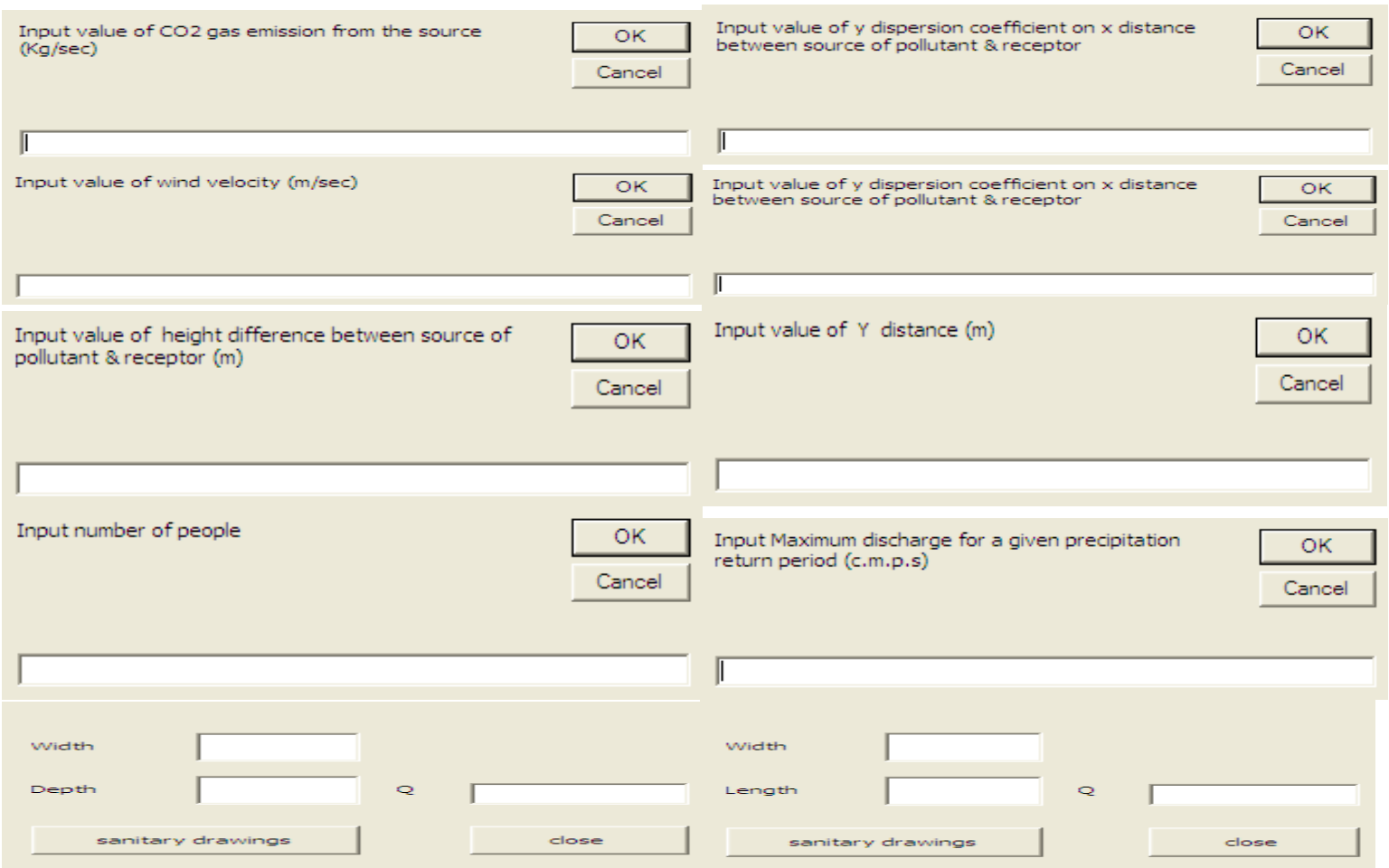

Fig. 3 The front ends of a useful geoinformatic utility to protect public health.

In figure 3 the examining input values of the investigated geoinformatic utility are based on parameters of the presented below formulas. 


$$
C(x, y, 0, H)=\left[\exp \left(-\frac{1}{2} \frac{y^{2}}{\sigma_{y}{ }^{2}}\right)\right] \frac{\Omega}{\pi u \sigma_{y} \sigma_{z}} \exp \left(-\frac{1}{2} \frac{H^{2}}{\sigma_{z}^{2}}\right)
$$

where:

$\mathrm{Q}$ are gas emissions from the source $(\mathrm{Kg} / \mathrm{sec})$;

$\mathrm{C}$ - air pollutant concentration at location $\mathrm{x}, \mathrm{y}$ on a height $\mathrm{H}\left(\mathrm{Kg} / \mathrm{m}^{\wedge} 3\right)$;

$\mathrm{U}$ - wind velocity $(\mathrm{m} / \mathrm{sec})$;

$\mathrm{x}$ - the respective $\mathrm{x}$ distance on $\mathrm{x}$ axis, from the source of air pollutant to a nearby civic, industrial or agricultural land use receptor area, the selected $\mathrm{x}$ distance determines the value of dispersion $\mathrm{y}$ that is defined from relative nomographs and tables according the literature;

$\mathrm{y}$ - the respective y distance from the centre line of air pollutant plume, from the source of air pollutant to a nearby civic, industrial or agricultural land use receptor area, the selected y distance determines the value of dispersion $\mathrm{z}$ that is defined from relative nomographs and tables according the literature.

The demanded air ventilation per time is calculated based on the mass balance the produced carbon dioxide volume $(\mathrm{P})$ per time in a closed space is described by the next formula:

$$
P=(\text { number_people }) *\left(C_{\text {_transpiraion }}-C_{\text {_respiration }}\right) *(\text { respiration_volume_per_time })
$$

where,

$\mathrm{P}$ are the production of carbon dioxide per time (cubic meters per hour, c.m.p.h);

Number_people - number of working staff in a greenhouse;

C_transpiration - outdoor space source air pollutants;

C_respiration - concentration per volume of respiration;

Respiration_volume_per_time - respiration volume (cubic meters per hour, c.m.p.h).

Also the demanded air ventilation per time is calculated based on the next formula

$$
C \max =C_{o}+\frac{P}{F}
$$

where,

Cmax are maximum concentration limit per volume for a pollutant in closed space, i.e. for carbon dioxide is 0,5 $\%$ per volume;

Co - the initial respiration volume per time;

$\mathrm{P}$ - the production of carbon dioxide per time (c.m.p.h);

$\mathrm{F}$ - the demanded air ventilation per time (c.m.p.h).

In equation (7) with the knowledge of $F(X)$ can be found $P(X)$ and the average recurrence interval $(T(X))$ for a certain size of flow, and a precipitation value $\mathrm{X}$. The extreme $\mathrm{X}$ precipitation hydrological event and flow rate for a given land area can be calculated based on time series analysis and the next formulas for Gumbel distribution [21]. It is assumed that the data fits a Gumbel distribution then is used the method of moments to calculate $\mathrm{F}(\mathrm{X})$ values. Moments are statistical descriptors of a data set. The first moment of a dataset is the mean; the second moment the standard deviation; the third moment skewness; the fourth kurtosis. Based on the next formulae for a given data set first is found the mean $\bar{Q}$, and the standard deviation of the annual maximum data series [5].

$$
\begin{gathered}
F(X)=e^{-e^{-b(X-a)}} \\
a=\bar{Q}-\frac{0.5772}{b}
\end{gathered}
$$




$$
\begin{gathered}
b=\frac{\pi}{\sigma_{Q} \sqrt{6}} \\
X=a-\frac{1}{b} \ln \ln \left(\frac{T(X)}{T(X)-1}\right)
\end{gathered}
$$

Moreover, in equation (8) is presented the hydraulic radius that should be taken into account for the right design in dimentions of a rectangular shape open canal, where $b$ is the width and $h$ the depth of the open canal for small top soil inclinations $2 \%-3 \%$. It is useful for a given extreme flow rate event, avoiding associated environmental impacts so as to protect public health. Also could be selected additional pumping manufactures for extreme cases protecting agricultural resources as well as mitigation of associated public health hazards from the overflow in open surface canals avoiding diffusion of polluted aquatic discharges.

$$
R=\frac{b \cdot h}{b+2 h}
$$

\section{PROJECT MANAGEMENT OF MANUFACTURES BY THE APPLICATION OF EFFICIENT LINING METHODS AND THE UTILIZATION OF ORTHOPHOTOMAPS}

The results are presented below of the examining geoinformatic utility that could be used for the right project management of manufactures for environmental protection in associated agricultural infrastructures $[9,15,17]$.

In Table 1 are presented different investigated scenarios for a greenhouse that is close to a batch landfill waste mass bioreactor. For the manufactures' ventilation capacity a greenhouse facility was selected with a nominal

\begin{tabular}{|c|c|c|c|c|c|c|}
\hline \multirow{2}{*}{ Ü } & \multicolumn{6}{|c|}{$\begin{array}{c}\text { Greenhouse volume } \\
1064 \mathrm{~m}^{\wedge} 3 \\
\end{array}$} \\
\hline & $\mathrm{H}(\mathrm{m})$ & People & $\mathrm{V}\left(\mathrm{m} \cdot \mathrm{s}^{-1}\right)$ & $X(m)$ & P (c.m.p.h) & F (c.m.p.h) \\
\hline 1. & 5 & 20 & 7 & 100 & 0.4 & 85.2 \\
\hline 2. & 10 & 20 & 10 & 200 & 0.39 & 84.6 \\
\hline 3. & 5 & 40 & 10 & 100 & 0.83 & 176.7 \\
\hline 4. & 10 & 40 & 10 & 200 & 0.8 & 170.1 \\
\hline
\end{tabular}
volume $1064 \mathrm{~m}^{3}$.

Table 1. Investigated case studies of a useful geoinformatic utility.

Based on the above results we can see that the $\mathrm{P}$ value production of carbon dioxide air pollutant in a receptor of a greenhouse construction and source from passive vents from a landfill, it depends on distance $\mathrm{X}$, wind velocity as well as on $\mathrm{H}$ magnitudes. In table 1 the $\mathrm{Y}$ value is the same $\mathrm{Y}=10 \mathrm{~m}$, assuming two points on the left and right from the center line of the plume of the source air pollutant on that distance. Also as input value of carbon dioxide source air pollutant is taken the value of $0.002475 \mathrm{Kg} / \mathrm{s}$ based assuming $50 \%$ per volume carbon dioxide in landfill gas and on a given 38 c.m.p.h landfill gas production magnitude $[17,20]$. The manufactures' ventilation capacity is calculated from the column of $\mathrm{F}$ parameter so as to protect public health. For the first two case studies the weather is classified in category A, sunny during day and for the last two ones the weather conditions are in category $\mathrm{D}$, cloudy sky during night.

Although the air ventilation is necessary for greenhouses' indoor quality, the heating also especially in winter period should be taken into account for the right operational selection of the manufactures that are needed for heating. In this way indoor microclimate quality is secured avoiding thermal pollution effect for working staff and associated environmental impacts in a greenhouse facility.

Assuming that will happen an event with maximum precipitation $=90 \mathrm{~mm}$ in the next ten years based on extrapolation of a given data set of the last five years annual data sets it yields 9 c.m.p.h for a $100 \mathrm{s.m}$ slope adjacent to the greenhouse facility. The latter means according to the hydraulics of a rectangular open canal that 
for an average $5 \mathrm{~m} / \mathrm{sec}$ water surface peak flow the dimensions of the open canal's sanitary drawing should be $2 \mathrm{~m}$ width and $0.9 \mathrm{~m}$ depth. The open canal should be anchored properly in case of heavy debris flows rates and other discharges depending on topographic characteristics. In such cases pumping equipement should be supported for nearby soil protection and agricultural resources facilities. Periodic monitoring and maintenance is demanded for the operational management of agricultural facilities.

Indicative sanitary drawings are presented below in figure 3 for the demanded air ventilation as well as the canal dimensions so as to minimize the environmental impacts based on the results of the presented geoinformatic utility. The sanitary drawings are created automatically based on given front ends' input data and the proper formation of VBA macros in ACAD environment. In figure 4 the results are useful for the operational management, maintenance, monitoring and associated project management of agricultural facilities and public health protection.
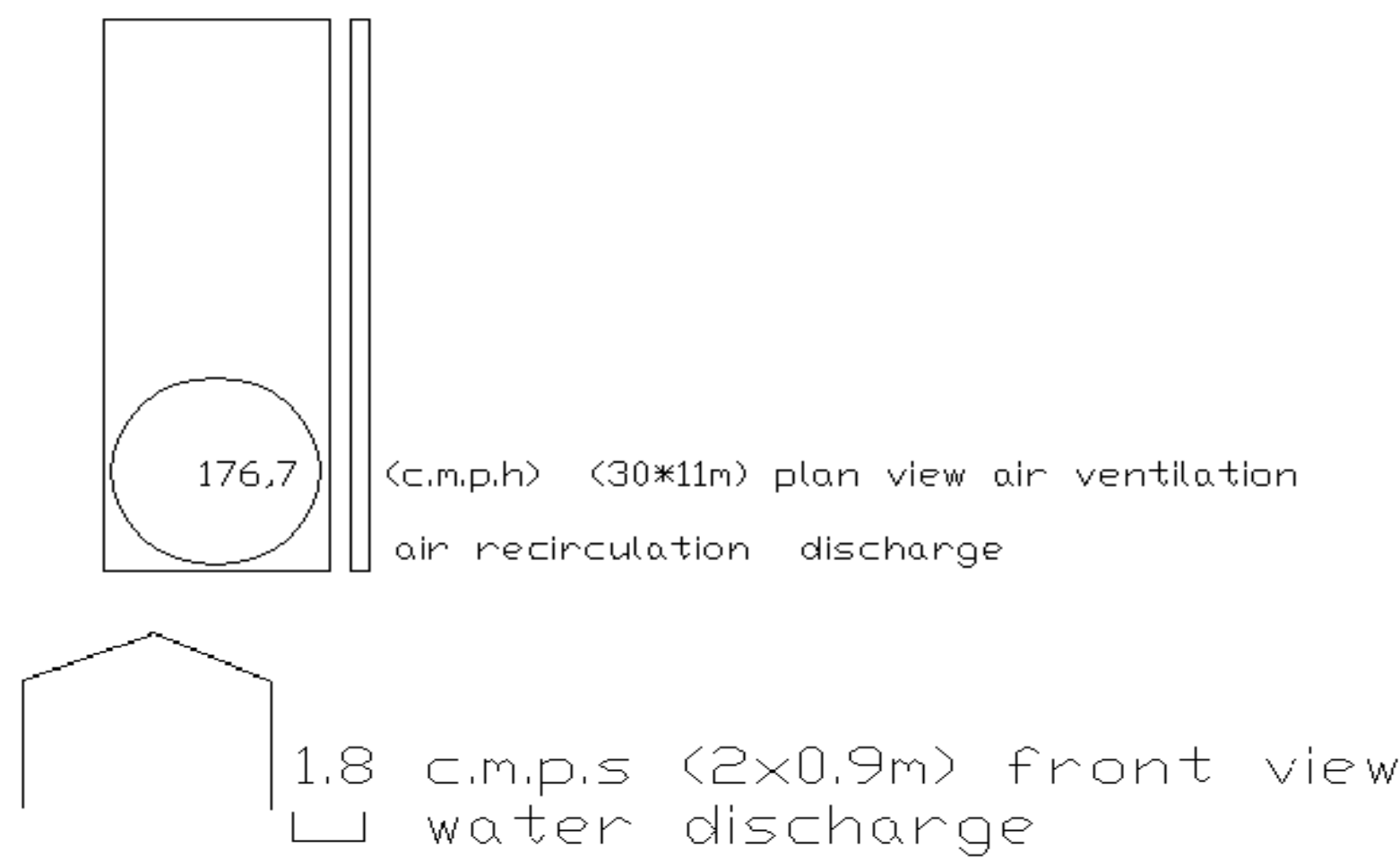

Fig. 4 Automated sanitary drawings in ACAD of a useful geoinformatic utility to protect public health.

\section{CONCLUSIONS}

The development of useful geoinformatic and sanitary drawings utilities are necessary for public health protection, environmental impact minimisation and their combination with dynamic spatial numerical simulation models for efficient public health protection. The results of the presented geoinformatic utility should be used for health inspection, right operational management of particular manufactures' automation control system analysis and savings of energy resources on a given agricultural facility. Effective software tools could be used by stakeholders based on above presented software development methodologies so as to be friendly for users, comprehensive and easily accessible to any interest party within project management of manufactures, lining of rescue or reclamation technical works, monitoring, project management and public health protection. The presented methodology is efficient as it could be easily applied on several agricultural facilities combined with remote engineering tools like google earth for extra data sets on a given topography and risk management scenarios protecting associated constructions and working staff in a greenhouse construction.

Moreover, landfill gas explosions are probable, noises produced from explosions as well as fires under favourable circumstances due to landfill gas migration. Therefore proper fire protection design in nearby agricultural constructions will avoid total collapse of agricultural facilities and additional air pollutants and 
environmental impact on agricultural resources. Also noise protection design is demanded due to explosions as well due to manufacture operation protecting working staff's public health.

The development of useful geoinformatic utilities for environmental impacts minimisation and their combination with dynamic spatial numerical simulation models and digital sanitary drawing utilities are useful for efficient spatial data manipulation not only of particular manufactures' automation control system analysis but also for the protection and save of associated economic agricultural and food geographic resources on given topographies. Effective software tools could be developed by students or graduates based on above presented software methodologies so as to be easy readable, comprehensive and easily accessible to any interest party and stakeholders within project management of manufactures and lining of rescue or reclamation technical works for public health protection in extreme natural and weather events.

\section{REFERENCES}

[1] Aldrich, T., Griffith, J., Environmental epidemiology and risk assessment, (Ed. Cooke, C.), Van Nostrand Reinhold, New York, U.S.A., 1993.

[2] Clay, H., Public health inspector's handbook: A manual for public health officers, Lewis, USA, 1968.

[3] Koschmidder, D., Brown, D., Elastic design of single-span stell portal frame buildings to eurocode3, Steel Construction Institute, UK, 2012.

[4] Blackman, C., Paige, C., Cuffaro, N., Sears, L., Industrial design, Rockport, USA, 2013.

[5] Davie, T., Fundamentals of hydrology, Routledge, USA, 2008.

[6] EN 1993-1-2 Eurocode 3: steel design structures, Belgium, 2005.

[7] Crowder, D.A., Google earth, for Dummies, 2007.

[8] Hughes, A. Electric motors and drives, Elsevier, 2006.

[9] Jones, C.B., Geographical information systems and computer cartography, Longman Press, 1997.

[10] Koliopoulos, T., Koliopoulou, G., Evaluating landfill chemical emissions - Mid auchencarroch experimental design, Asian Journal of Chemistry, vol. 19, no.5, 2007, p. 3911-3917.

[11] King, C.M., Plastic design of single-storey pitched-roof portal frames to Eurocode 3, Steel construction institute, Technical report, SCI Publication 147, 1995.

[12] Koliopoulos, T., Kollias, V., Kollias, P., Modelling the risk assessment of groundwater pollution by leachates and landfill gases, In Transactions on Water Pollution of Wessex Institute of Technology, Water Pollution, vol. II, 2003, p. 159-169.

[13] Koliopoulos, T., Koliopoulou, G., A diagnostic model for M.S.W landfill operation and the protection of ecosystems with a spatial multiple criteria analysis - Zakynthos Island, Greece, In Transactions on Ecology and the Environment of Wessex Institute of Technology, Ecosystems and Sustainable Development, vol. I, 2007, p. 449-461.

[14] Koliopoulos, T., Koliopoulou, G., Evaluation of optimum landfill design: mid auchencarroch experimental landfill emissions, In Transactions on Computer Aided Optimum Design in Engineering of Wessex Institute of Technology, Computer Aided Optimum Design in Engineering of Wessex Institute of Technology, vol. X, 2007, p. 231-239.

[15] Koliopoulos, T., An efficient methane greenhouse emissions' flushing out at mid auchencarroch experimental landfill site and proposed effective linings of biogas collection monitoring networks, Rasayan Journal of Chemistry, vol. 1, no. 3, 2008, p. 437-446.

[16] American CGIHR, Industrial ventilation: a manual of recommended practice for Design, American C.G.I Hygienists, 2013.

[17] I.S.O. 14001:2015, Standards and regulations for investigation, monitoring, management, certification and improvement of environmental systems, I.S.O. Publications, 2015.

[18] Mackenzie, D., Cornwell, D. Introduction to environmental engineering, McGraw Hill, USA., 1998.

[19] Ripley, B., Spatial statistics, John Wiley \& Sons Pubs, New Jersey, U.S.A., 2004.

[20] Alexander, M., Kusleika, R., Excel 2016 power programming with VBA, Wiley publications, 2016.

[21] Cottingham, M., Mastering AutoCAD VBA, Sybex publications, 2001.

[22] Jerke, N., Visual Basic 6: The complete reference, Osborne. McGraw Hill Pubs, 1999.

[23] Koutsopoulos, K., Analysis of space: theory, methodology and techniques, Deenaikais Publications, Athens, Greece, 2006.

[24] Koschmidder, D., Brown, D., Elastic design of single-span stell portal frame buildings to Eurocode3, Steel Construction Institute, UK, 2012.

[25] Leroy, G., Nethercot, D. Designers' guides to Eurocode 3, ICE, UK, 2011. 
[26] Satler, P., Malik, A., King, C., Design of single-span steel portal frames to BS 5950-1:2020, Steel Construction Institute U.K., 2004.

[27] Politakis, J., Environmental agriculture, Psichalou publications, Greece, 2003.

[28] Ciarkowska, K., Hanus-Fajerska, E., Gambus, F., Muszynska, E., Czech T., Phytostabilization of Zn-Pb ore flotation tailings with dianthus carthusianorum and biscutella laevigata after amending with mineral fertilizers or sewage sludge. Journal of Environmental Management, vol. 189, 2017, p. 75-83.

[29] Kolodziej, B., Antonkiewicz, J., Sugier, D., Miscanthus $\times$ giganteus as a biomass feedstock grown on municipal sewage sludge. Industrial Crops and Products, vol. 81, 2016, p. 72-82. 